Florida A\&M University College of Law Scholarly Commons@ FAMU Law

Course Descriptions and Information

Legal Clinic Program

2016

\title{
Community Economic Development
}

Legal Clinic Program

Florida A $M$ University College of Law

Follow this and additional works at: http:// commons.law.famu.edu/course-descriptions

Part of the Business Organizations Law Commons, Intellectual Property Law Commons, Law and Economics Commons, Legal Education Commons, and the Privacy Law Commons

\section{Recommended Citation}

Program, Legal Clinic, "Community Economic Development" (2016). Course Descriptions and Information. Paper 2.

http://commons.law.famu.edu/course-descriptions/2

This Course Description is brought to you for free and open access by the Legal Clinic Program at Scholarly Commons @ FAMU Law. It has been accepted for inclusion in Course Descriptions and Information by an authorized administrator of Scholarly Commons @ FAMU Law. For more information, please contact linda.barrette@famu.edu. 
COMMUNITY ECONOMIC DEVELOPMENT (CED): This clinic emphasizes transactional practice skills. This clinic provides short term counseling in a broad range of small business matters such as corporations, limited liability companies, partnerships, intellectual property, copyright, trademark, privacy law, nonprofit organizations, art groups as well as the legal requirements for starting a small business. Students provide direct legal assistance, counseling, representation, community legal education, and informational materials to new and mature for-profit and non-profit organizations, individuals and community groups seeking to better the economic, social, equitable and cultural well-being of low income communities. Assistance may be provided to groups that promote community and economic development in areas such as: community preservation, development and empowerment; drug prevention; homelessness; literacy; microenterprise development; social welfare; youth and teen development; entrepreneurship; and low income and affordable housing. The clinic is designed to provide students interested in business law with a clinical experience that will expose them to the practical and substantive problems of issues related to counseling small businesses and nonprofit organizations. Students develop collaborative work skills and interpersonal skills in group work. They explore the growing area of community economic development law and other areas that underlie efforts to enhance the economic viability of the community. The students are encouraged to observe proceedings in the Business Court.

Pre-requisite: Professional Responsibility. No Bar clearance required at this time.

Credits-6

Course No. $6948 \quad$ Class No. $4849 \quad$ Sec. 301 